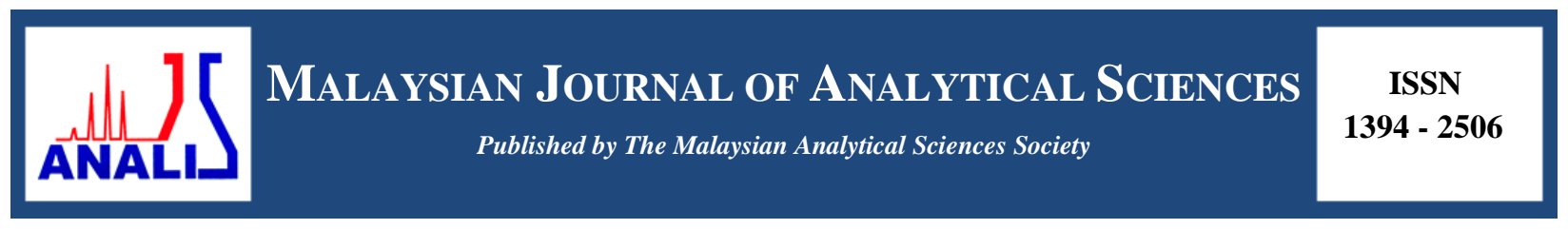

\title{
OPTIMIZATION OF ACTIVATED CARBON PREPARATION FROM SPENT MUSHROOM FARMING WASTE (SMFW) VIA BOX-BEHNKEN DESIGN OF RESPONSE SURFACE METHODOLOGY
}

\author{
(Penyediaan Secara Optimum Arang Teraktif daripada Sisa Tanaman Cendawan Terpakai \\ (SMFW) Melalui Reka Bentuk Box-Behnken dari Kaedah Gerak Balas Permukaan) \\ Nurul-Shuhada Md-Desa ${ }^{1}$, Zaidi Ab Ghani ${ }^{2}$, Suhaimi Abdul-Talib ${ }^{3}$, Chia-Chay Tay ${ }^{2 *}$ \\ ${ }^{1}$ Faculty of Applied Sciences \\ Universiti Teknologi MARA, 40450 Shah Alam, Selangor, Malaysia \\ ${ }^{2}$ Faculty of Applied Sciences, \\ Universiti Teknologi MARA, 02600 Arau, Perlis Malaysia \\ ${ }^{3}$ Faculty of Civil Engineering \\ Universiti Teknologi MARA, 40450 Shah Alam, Selangor, Malaysia \\ *Corresponding author: taychiay@perlis.uitm.edu.my
}

Received: 9 December 2014; Accepted: 22 March 2016

\begin{abstract}
This study focuses on activated carbon preparation from spent mushroom farming waste (SMFW) via chemical activation using Box-Behnken design (BBD) of Response Surface Methodology (RSM). Potassium hydroxide (KOH) functions as activating reagent and it plays an important role in enhancing the activated carbon porosity. Three input parameters and two responses were evaluated via this software generated experimental design. The effects of three preparation parameters of impregnation ratio, activation time and activation temperature as well as two responses of carbon yield and iodine number were investigated. The optimum conditions for preparing activated carbon from SMFW was found at SMFW: KOH impregnation ratio of 0.25 , activation time of $30 \mathrm{~min}$ and activation temperature of $400{ }^{\circ} \mathrm{C}$ which resulted in $28.23 \%$ of carbon yield and $314.14 \mathrm{mg} / \mathrm{g}$ of iodine number with desirability of 0.994 . The predicted results were well corresponded with experimental results. This study is important in economical large scale SMFW activated carbon preparation for application study of adsorption process for metal treatment in wastewater with minimum chemical and energy input.
\end{abstract}

Keywords: activated carbon, spent mushroom farming waste, Box-Behnken design, response surface methodology

\section{Abstrak}

Kajian ini memfokuskan penyediaan arang teraktif daripada sisa tanaman cendawan terpakai melalui reka bentuk box-behnken (BBD) dari kaedah gerak balas permukaan (RSM). Potasium hidroksida (KOH) berperanan sebagai agen pengaktifan dan penting untuk meningkatkan liang arang teraktif. Tiga parameter input dan dua respon telah dinilai oleh perisian ini yang dihasilkan oleh rekabentuk eksperimen. Kesan daripada penyediaan tiga parameter iaitu nisbah pemadatan, masa pengaktifan dan suhu pengaktifan serta dua respon iaitu hasil arang teraktif dan nilai iodin telah disiasat. Keadaan optimum dalam penyediaan arang teraktif telah didapati pada nisbah SMFW: KOH iaitu 0.25, tempoh pengaktifan selama 30 min dan suhu pengaktifan 400 ${ }^{\circ} \mathrm{C}$, di mana ia menghasilkan jumlah maksimum arang teraktif sebanyak $28.23 \%$ dan nilai iodin yang boleh diterima iaitu sebanyak $314.14 \mathrm{mg} / \mathrm{g}$ dengan ketepatan 0.994. Keputusan yang telah diramalkan adalah seiring dengan keputusan eksperimen. Kajian ini adalah penting dalam penyediaan arang teraktif secara berskala besar dengan ekonomi daripada sisa tanaman cendawan terpakai untuk kajian proses penjerapan terhadap rawatan logam dalam air sisa dengan input bahan kimia dan tenaga yang minimum. 


\section{Nurul-Shuhada et al: OPTIMIZATION OF ACTIVATED CARBON PREPARATION FROM SPENT MUSHROOM FARMING WASTE (SMFW) VIA BOX-BEHNKEN DESIGN OF RESPONSE SURFACE METHODOLOGY}

Kata kunci: karbon teraktif, sisa tanaman cendawan terpakai, reka bentuk Box-Behnken, kaedah gerak balas permukaan

\section{Introduction}

Activated carbon (AC) is a carbonaceous material with large surface area and high porosity. The surface area and pore size distribution are important factors in determination of AC performance. The macropores act as the entrance to the AC, while the mesopores and micropores responsible for adsorption process determined by iodine number. Iodine number is important parameter to indicate the quality of carbon porosity by measuring the amount of iodine adsorbed (in milligrams) by $1 \mathrm{~g}$ of carbon using standard method of ASTM D4607-94. On the other hand, the percentage yield in activated carbon preparation plays a major role in continuous supply for application.

Generally, optimization of AC preparation is via traditional method. However, response surface methodology (RSM) has been found to be a useful tool to optimize AC preparation. Box-Behnken design (BBD) is one of RSM method with an independent quadratic design. It does not contain an embedded factorial or fractional factorial design. In this design, the treatment combinations are at the midpoints of edges of the process space and at the center. The BBD is favourable due to its less number of experiments with variable parameter consuming less time.

Most of the study had reported in multiple input parameters such as impregnation ration (IR), activation time and activation temperature. Precusors from agricultural wastes such as flamboyant (Delonix regia) pods [1], Prosopisafricana seed hulls [2], Borassus aethiopum shells [3] and coconut husk [4] have been studied. Spent mushroom farming waste (SMFW) is a low cost agricultural based material, abundantly available and is a renewable resource. The SMFW consists of sawdust and rice husk majorly. Previous study using sawdust as AC by Foo \& Hameed [5] and Moodley et al.[6] and rice husk as AC by Khan et al.[7], Chen et al.[8], Kumagai et al.[9] and Ding et al.[10] have generated highly porous carbonaceous carbon. These reports showed that both components of sawdust and rice husk are suitable as a potential precursor. Thus, SMFW has been selected as precursor for this study as there is lack of literature study on utilization of sawdust and rice husk combination medium of SMFW AC preparation and application.

The aim of this study is to optimize SMFW AC preparation parameters of impregnation ratio (IR) between KOH and SMFW, activation time and activation temperature. The analysis involve multiple responses of percentage yield and iodine number via BBD of RSM method.

\section{Materials}

\section{Materials and Methods}

Spent mushroom farming waste (SMFW) used for preparation of activated carbon was provided by $\mathrm{C} \& \mathrm{C}$ Mushroom Cultivation Farm, Johor, Malaysia.

\section{Characterization of the activated carbon}

The AC surface morphology was analyzed using Field Emission Scanning Electron Miscroscope (FESEM) of ZEISS Supra 40VP at voltage of $5 \mathrm{kV}$ and 12000 magnifications. The Fourier Transform Infrared (FTIR) spectra were analyzed using Series 100 PerkinElmer Fourier Transform Infra-Red (FTIR) spectroscopy in the range of 400 $-4000 \mathrm{~cm}^{-1}$ for surface functional groups identification. Thermogravimetric analyzer (TGA) TA Model SDT Q600 V8.3, under nitrogen gas atmosphere with heating condition following the ASTM D2974 was conducted.

\section{Activated carbon preparation via Box-Behnken Design}

The preparation of AC from SMFW was accomplished using sodium hydroxide (KOH) as activating agent. The SMFW was impregnated with the $\mathrm{KOH}$ for 24 hours respectively. The slurry was then dried at $80{ }^{0} \mathrm{C}$ for 24 hours. The impregnate precursor was carbonized in furnace. The produced char was washed with hydrochloric acid and distilled water to remove residual $\mathrm{KOH}$ and dried at $80{ }^{\circ} \mathrm{C}$. Finally, the prepared AC was sieved to size of 150 micrometer and kept in drying cabinet prior to use. The experiments were applied using parameter set by BBD of RSM method. The variables studied were (i) $x 1$, KOH: SMFW impregnation ratio; (ii) $x 2$, activation time and (iii) $x 3$, activation temperature. The experimental sequence was randomized in order to minimize the effects of the uncontrolled factors [3]. The two responses were carbon yield $\left(\mathrm{Y}_{1}\right)$ and iodine number $\left(\mathrm{Y}_{2}\right)$. Each response was used to develop an empirical model which correlated the response to the three activated carbon preparation parameters. 
The percentage of activated carbon yield was calculated as equation (1). Iodine test was conducted according to ASTM D4607method and calculation as shown in equation (2) below:

$$
\begin{aligned}
& \text { Percentage yield }(\%)=\frac{\text { Weight of activated carbon }}{\text { Weight of dried SMFW }} \times 100 \\
& \frac{\mathrm{X}}{\mathrm{M}}=\frac{[\mathrm{A}-(\mathrm{DF})(\mathrm{B})(\mathrm{S})]}{\mathrm{M}}
\end{aligned}
$$

where $\mathrm{X} / \mathrm{M}$ is defined as iodine adsorbed per gram of carbon $(\mathrm{mg} / \mathrm{g})$, A is defined as normality of iodine solution $\mathrm{X}$ 12693 , DF is defined as dilution factor (2.2), B is defined as normality of sodium thiosulfate solution $\times 126.93, \mathrm{~S}$ is defined as sodium thiosulfate used for every titration $(\mathrm{mL})$ and $\mathrm{M}$ is defined as weight of activated carbon used.

\section{Characterization of the activated carbon}

\section{Results and Discussion}

The SEM image of SMFW AC is shown in Figure 1. The SMFW AC has a rough surface with different size of pores. The large irregular structure of pores in the AC external surface indicated the macropores with linkage of mesopores and micropores rooting inside the internal structure of AC. Formation of the pores corresponded to the formation of metallic potassium $(\mathrm{K})$ through activation process using $\mathrm{KOH}$ as activating agent. Intercalation of $\mathrm{K}$ in the carbon structure widened the existing pores and developed new porosity essential for adsorption process.

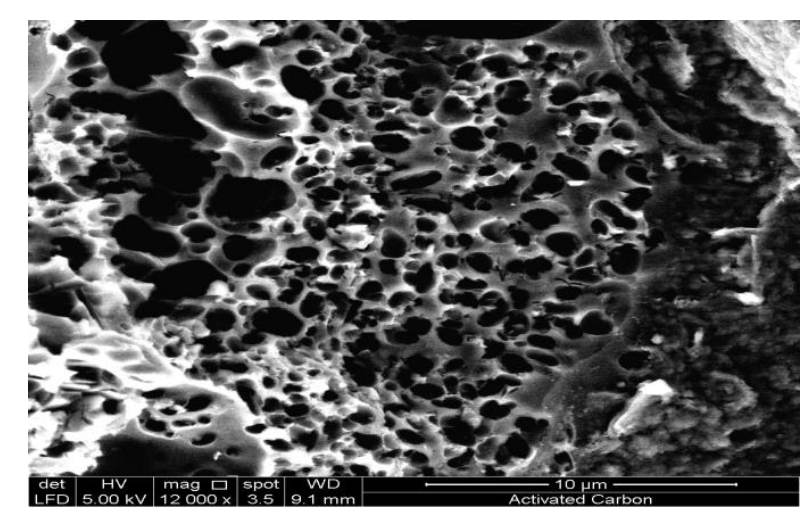

Figure 1. SEM image of SMFW activated carbon

Figure 2 shows the FTIR image of SMFW AC to determine the AC surface chemistry of functional groups. From the spectra, the band at $3405 \mathrm{~cm}^{-1}$ was attributed to the hydrogen bond between $-\mathrm{OH}$ in the AC surface or $-\mathrm{OH}$ in water molecule [11]. Besides, band at $1384 \mathrm{~cm}^{-1}$ was attributed to stretching vibration of C-N bond [12] and band at $1714 \mathrm{~cm}^{-1}$ was attributed to the $\mathrm{C}=\mathrm{O}$ stretching bond of ketone [13]. The $\mathrm{N}-\mathrm{H}$ stretch bond at band $3500 \mathrm{~cm}^{-1}$ represented amine group in the AC.

Figure 3 demonstrates the TGA/DTG curve thermogravimetry (TG) of AC and its derivatives represented by green line and blue line respectively. The TGA curve showed three phases of AC weight loss. The first stage was the moisture elimination of $3.4 \%$ below temperature of $200{ }^{\circ} \mathrm{C}$. Next, second stage weight loss of $26 \%$ was due to the degradation of hemicelluloses, cellulose and lignin occurred at temperature $200-500{ }^{\circ} \mathrm{C}$ [14]. According to the previous study by Yang et al. [15], hemicelluloses started to degrade at $220{ }^{\circ} \mathrm{C}$ and completed at $315{ }^{\circ} \mathrm{C}$ while degradation of cellulose occurred between $315-390{ }^{\circ} \mathrm{C}$. Stronger structure of lignin degraded in a wider temperature range than the other two components. The third stage involved weight loss according to the weight loss of $51.2 \%$ volatile matter at temperature $500-900{ }^{\circ} \mathrm{C}$. The same results have been reported in literature by Gao et al. [14], Zhang et al. [16] and Domingueza et al. [17]. The DTG curve of Figure 4 shows a significant change occurred due to the weight loss of AC starting of the degradation of hemicelluloses, cellulose and lignin. This was 


\section{Nurul-Shuhada et al: OPTIMIZATION OF ACTIVATED CARBON PREPARATION FROM SPENT MUSHROOM FARMING WASTE (SMFW) VIA BOX-BEHNKEN DESIGN OF RESPONSE SURFACE METHODOLOGY}

explained by the fact that hemicelluloses and cellulose compounds have the structure of branching chain of polysaccharides without aromatic compound, which are easily volatilized. Meanwhile, lignin consists of various O- and C-C functional groups and aromatic structural units [18].

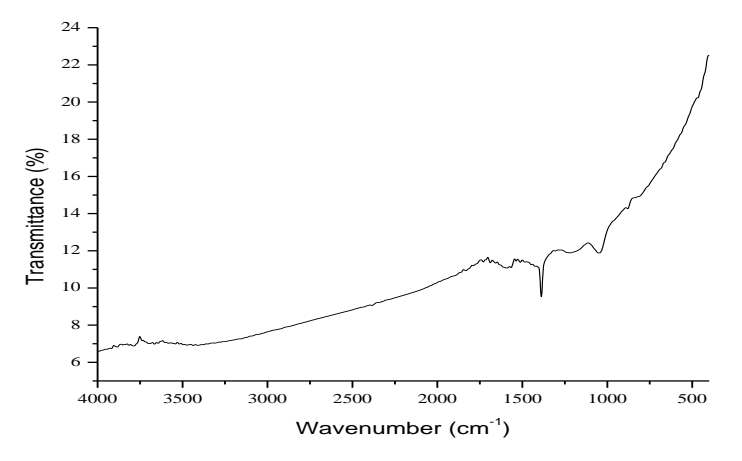

Figure 2. FTIR image of SMFW AC

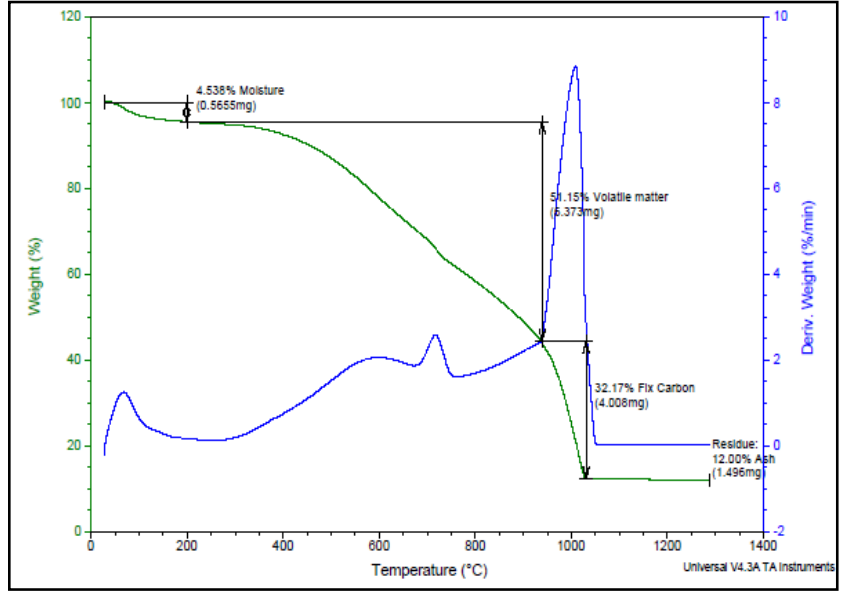

Figure 3. TGA/DTG image of SMFW AC

\section{Optimization of parameters on carbon yield}

Figure $4(\mathrm{a}-\mathrm{c})$ illustrate the 3-D response surface plots of percentage yield on AC as a function of three process parameters of impregnation ratio, activation time and activation temperature.

Figure 4 (a) shows the effect of impregnation ratio and activation time on the percentage yield. There are only little effect of time on yield. However, decreasing of yield with increasing ratio was observed which was due to increase of the carbon burn-off. Increased the impregnation ratio has resulted increased the weight loss of releasing the volatile matter from the intensifying dehydration and elimination reactions [4]. This is supported by Muthanna et al.[19] using Siris seed pods. Figure 4 (b) shows the effect of impregnation ratio and activation temperature on the percentage yield. When the ratio and temperature increased, the percentage yield of carbon was decreased. This was due to higher elimination of tars in the pores. Sentorun-Shalaby et al. [20] reported that at higher activation temperature, activation of apricot stones became more extensive and resulted in a lower solid yield with a more 
widened porous structure. Figure 4 (c) shows the effect of activation time and activation temperature on the percentage yield. As the temperature increased, the percentage yield of carbon was decreased. Meanwhile, activation time did not have significant effect on the percentage yield since heating duration of AC only affect it's surface area. This is supported by Tan et al. [4] study on coconut husk AC.

(a)

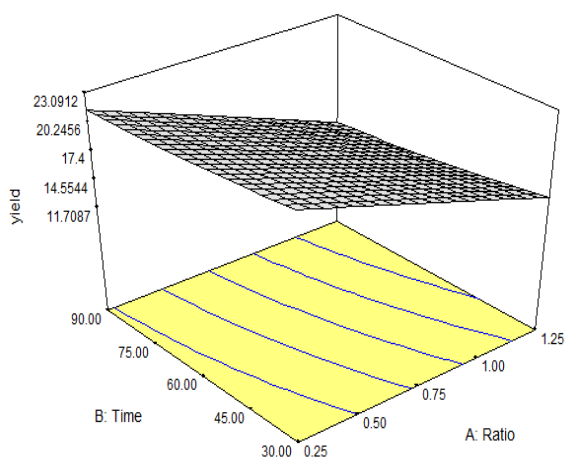

(b)

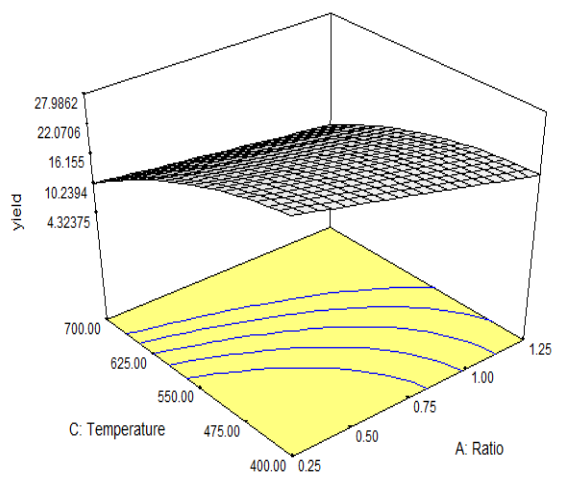

(c)

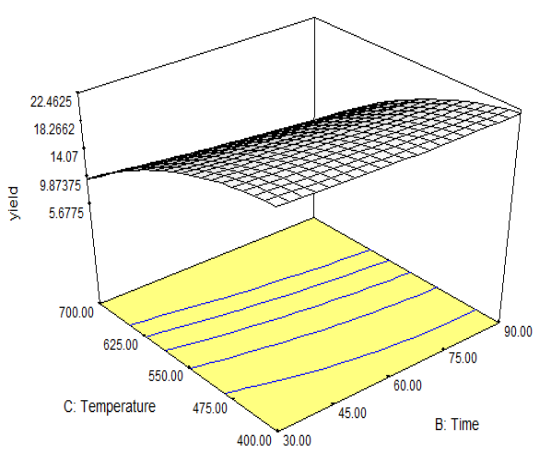

Figure 4. (a) Response for the effect of ratio KOH: SMFW and activation time on percent yield, (b) Response for the effect of ratio KOH: SMFW and activation temperature on percent yield and (c) Response for the effect of activation time and activation temperature on percent yield

\section{Optimization of parameter on iodine number}

Figure 5(a-c) illustrate the 3-D response surface plots of iodine number for AC as a function of three process parameters of impregnation ratio, activation time and activation temperature. Figure 5(a) shows the effect of impregnation ratio and activation time on the iodine number of the prepared AC. The iodine number increased with increased of the impregnation ratio. The impregnation ratio plays an important role in the formation of pores and promotes catalytic oxidation simultaneously. The $\mathrm{KOH}$ served to increase porosity of $\mathrm{AC}$, thus resulted the raised in iodine number. This is supported by Abechi et al. [21] using KOH-kernel shell. Figure 5(b) shows the effect of impregnation ratio and activation temperature on the iodine number of prepared AC. As the activation temperature and impregnation ratio increased, the value of iodine number was increased. High temperature would increase the $\mathrm{C}-\mathrm{KOH}$ reaction rates, thus resulting in increasing devolatilization and development of the pore structure in the char. Muthanna et al. [19] reported similar observation using AC from Siris seed pods. Figure 5(c) shows the effect of activation time and activation temperature on the iodine number of carbon. Since both the activation time and activation temperature increased, the value of iodine number was also increased. Tham et al.[22] reported that longer activation time had generated more micropores and mesopores in the AC produced from durian shell. 


\section{Nurul-Shuhada et al: OPTIMIZATION OF ACTIVATED CARBON PREPARATION FROM SPENT MUSHROOM FARMING WASTE (SMFW) VIA BOX-BEHNKEN DESIGN OF RESPONSE SURFACE METHODOLOGY}

(a)

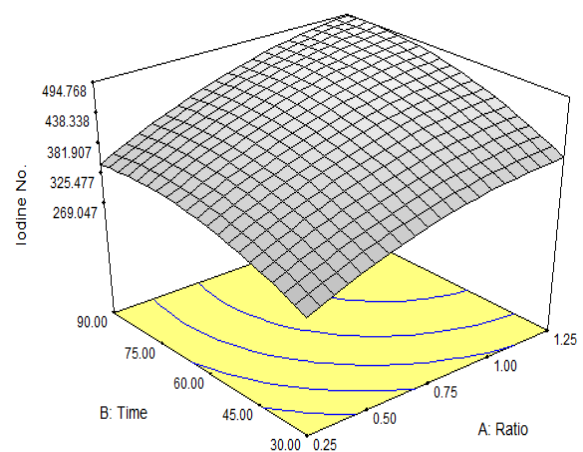

(b)

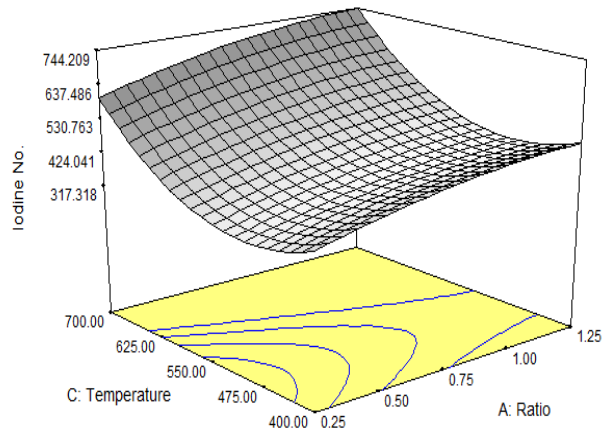

(c)

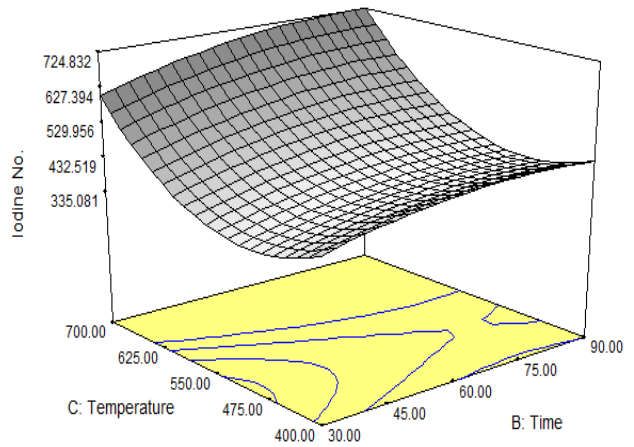

Figure 5. (a) Response for the effect of ratio KOH: SMFW and activation time on iodine number, (b) Response for the effect of ratio KOH: SMFW and activation temperature on iodine number, and (c) Response for the effect of activation time and activation temperature on iodine number.

\section{Comparisons between experimental data and predicted data of Box-Behnken design}

Final empirical models in terms of coded factors for carbon yield $\left(\mathrm{Y}_{1}\right)$ and iodine number $\left(\mathrm{Y}_{2}\right)$ are shown in equation (3) and (4), respectively.

$$
\begin{aligned}
\mathrm{Y}_{1}= & 17.48-4.56 \times x 1-1.13 \times x 2-7.27 \times x 3-0.045 \times x 1^{2}+0.26 \times x 2^{2}-2.83 \times x 3^{2}- \\
& 0.30 \times x 1 \times x 2+1.55 \times x 1 \times x 3-0.84 \times x 2 \times x 3 \\
Y_{2}= & 433.10+66.64 \times x 1+45.65 \times x 2+120.13 \times x 3-26.86 \times x 1^{2}-33.10 \times x 2^{2}+ \\
& 144.64 \times x 3^{2}+8.20 \times x 1 \times x 2+6.56 \times x 1 \times x 3+14.11 \times x 2 \times x 3
\end{aligned}
$$

Figure 6 shows the comparison between the experimental and predicted value of percentage yield and iodine number of AC. It was observed that there were good agreement between the experimental and predicted values of percentage yield and iodine number, which indicated the excellent reliability of the model with high $\mathrm{R}^{2}$ of 0.9804 and 0.9333 respectively. 

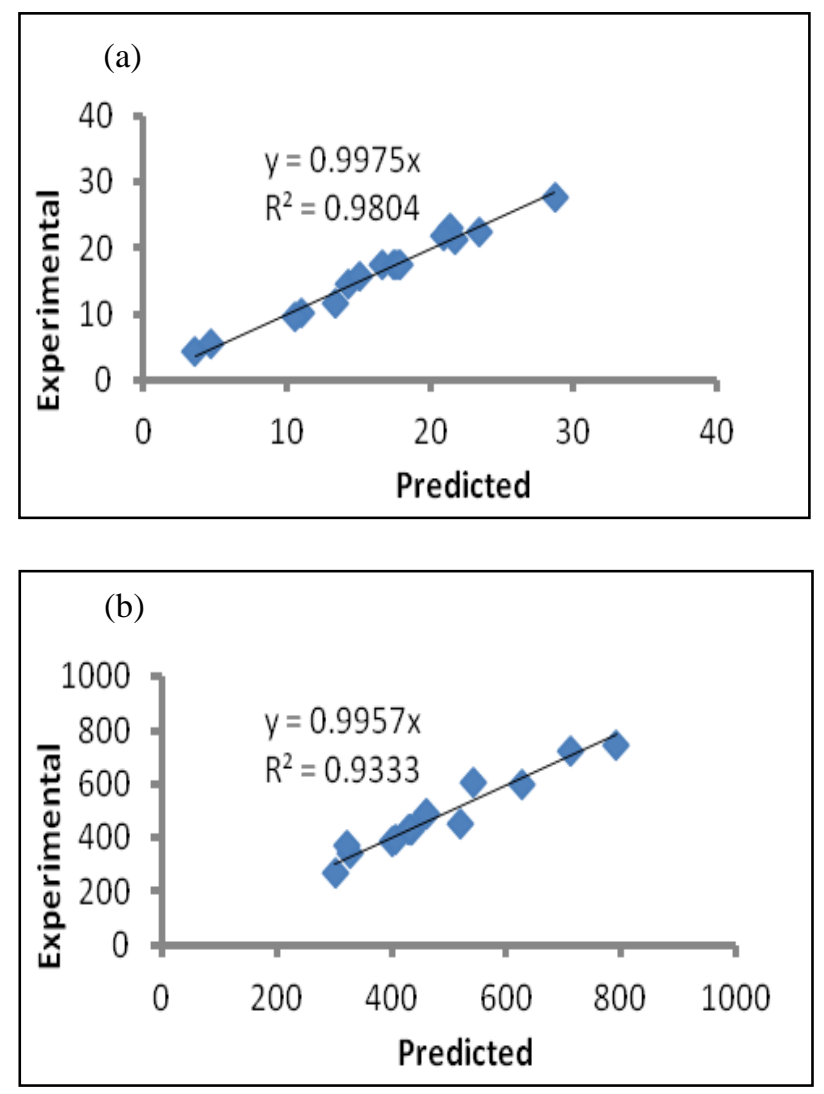

Figure 6. (a) Relationship between actual and predicted value of percentage yield of activated carbon, and (b) Relationship between actual and predicted value of iodine number of activated carbon.

\section{Conclusion}

Preparation of AC via Box-Behnken design of Response Surface Methodology was evaluated. The analysis of percentage yield and iodine number using this method generated optimum condition of impregnation ratio, activation time and activation temperature at $0.25,30.04 \mathrm{~min}$ and $400{ }^{\circ} \mathrm{C}$ respectively. Experimental result was well fitted to predicted result with high $\mathrm{R}^{2}$ of 0.9804 for percentage yield of $\mathrm{AC}$ and 0.9333 for iodine number. This method is applicable for industrial practice in $\mathrm{AC}$ production which involves multiple input and responses with minimum chemical and energy input, contribute on green technology.

\section{Acknowledgement}

The authors acknowledge the research grant RAGS, provided by the MOHE (RAGS/2013/UiTM/SG01/4), C\&C Mushroom Cultivation Farm Sdn. Bhd. and also Universiti Teknologi MARA for supporting the facility.

\section{References}

1. Vargas, A. M. M., Garcia, C. A., Reis, E. M., Lenzi, E., Costa, W. F. and Almeida, V. C. (2010). NaOHactivated carbon from flamboyant (Delonix regia) pods: Optimization of preparation conditions using central composite rotatable design. Chemical Engineering Journal, 162 (1): 43 - 50.

2. Garba, Z. N. and Rahim, A. A. (2014). Process optimization of $\mathrm{K}_{2} \mathrm{C}_{2} \mathrm{O}_{4}$-activated carbon from Prosopis africana seed hulls using response surface methodology. Journal of Analytical and Applied Pyrolysis, 107: 306 - 312.

3. Garba, Z. N., Abdul Rahim, A. and Hamza, S. A. (2014). Potential of Borassus aethiopum shells as precursor for activated carbon preparation by physico-chemical activation; optimization, equilibrium and kinetic studies. Journal of Environmental Chemical Engineering, 2(3): 1423 - 1433. 
Nurul-Shuhada et al: OPTIMIZATION OF ACTIVATED CARBON PREPARATION FROM SPENT

MUSHROOM FARMING WASTE (SMFW) VIA BOX-BEHNKEN DESIGN OF RESPONSE SURFACE METHODOLOGY

4. Tan, I. A. W., Ahmad, A. L. and Hameed, B. H. (2008). Preparation of activated carbon from coconut husk: optimization study on removal of 2,4,6-trichlorophenol using response surface methodology. Journal of Hazardous Materials, 153(1-2): 709 -717.

5. Foo, K. Y. and Hameed, B. H. (2012). Mesoporous activated carbon from wood sawdust by $\mathrm{K}_{2} \mathrm{CO}_{3}$ activation using microwave heating. Bioresource Technology, 111: $425-432$.

6. Moodley, K., Singh, R., Musapatika, E. T., Onyango, M. S. and Ochieng, A. (2011). Removal of nickel from wastewater using an agricultural adsorbent, Water SA, 37(1): $41-46$.

7. Yahaya, E. M., Faizal, M., Mohamed, P., Abustan, I. and Azmier, M. (2010). Effect of preparation conditions of activated carbon prepared from rice husk by $\mathrm{ZnCl}_{2}$ activation for removal of $\mathrm{Cu}$ (II) from aqueous solution. International Journal of Engineering Technology 10 (6): 1- 5.

8. Chen, Y., Zhu, Y., Wang, Z., Li, Y., Wang, L., Ding, L. and Guo, Y. (2011). Application studies of activated carbon derived from rice husks produced by chemical-thermal process - a review. Advances in Colloid and Interface Science 163(1): $39-52$.

9. Kumagai, S., Sato, M. and Tashima, D. (2013). Electrical double-layer capacitance of micro- and mesoporous activated carbon prepared from rice husk and beet sugar. Electrochimica Acta, 114: 617 -626.

10. Ding, L., Zou, B., Gao, W., Liu, Q., Wang, Z., Guo, Y. and Liu, Y. (2014). Adsorption of Rhodamine-B from aqueous solution using treated rice husk-based activated carbon. Colloids and Surfaces A: Physicochemical and Engineering Aspects, 446: 1 - 7.

11. Yao, X., Liu, J., Gong, G., Jiang, Y. and Xie, Q. (2013). Preparation and modification of activated carbon for benzene adsorption by steam activation in the presence of KOH. International Journal of Mining Science and Technology, 23(3): 395 - 401 .

12. ElShafei, G. M. S., ElSherbiny, I. M., Darwish, A. S., and Philip, C. A. (2014). Silkworms' feces-based activated carbons as cheap adsorbents for removal of cadmium and methylene blue from aqueous solutions. Chemical Engineering Research and Design, 92(3): 461 - 470.

13. Pezoti Junior, O., Cazetta, A. L., Gomes, R. C., Barizão, É. O., Souza, I. P. A. F., Martins, A. C. and Almeida, V. C. (2014). Synthesis of $\mathrm{ZnCl}_{2}$-activated carbon from macadamia nut endocarp (Macadamia integrifolia) by microwave-assisted pyrolysis: Optimization using RSM and methylene blue adsorption. Journal of Analytical and Applied Pyrolysis, 105: 166 -176.

14. Gao, Y., Yue, Q., Gao, B., Sun, Y., Wang, W., Li, Q. and Wang, Y. (2013). Preparation of high surface areaactivated carbon from lignin of papermaking black liquor by $\mathrm{KOH}$ activation for $\mathrm{Ni}(\mathrm{II})$ adsorption. Chemical Engineering Journal, 217: 345 - 353.

15. Yang, H., Yan, R., Chen, H., Lee, D. H. and Zheng, C. (2010). Characteristic of hemicellulose, cellulose and lignin pyrolysis. Fuel, 86(12): $1781-1788$.

16. Zhang, M., Resende, F. L. P., Moutsoglou, A. and Raynie, D. E. (2012). Pyrolysis of lignin extracted from prairie cordgrass, aspen and kraft lignin by Py-GC/MS and TGA/FTIR. Journal of Analytical and Applied Pyrolysis, 98: 65 - 71 .

17. Dominguez, J. C., Oliet, M., Alonso, M. V., Gilarranz, M. A. and Rodriguez, F. (2008). Thermal stability and pyrolysis kinetics of organosolv lignins obtained from Eucalyptus globulus. Industrial Crops and Products, 27(2): $150-156$.

18. Sharma, R. K., Wooten, J. B., Baliga, V. L., Lin, X.,Chan, W. G. and Hajaligol, M.R. (2004). Characterization of chars from pyrolysis of lignin. Fuels, 83(11): $1469-1482$.

19. Muthanna, J. A. and Samar K. T. (2013). Microporous activated carbon from Siris seed pods by microwaveinduced $\mathrm{KOH}$ activation for metronidazole adsorption. Journal of Analytical and Applied Pyrolysis, 99: 101 109.

20. Şentorun-Shalaby, Ç., Uçak-Astarlıg`lu, M. G., Artok, L. and Sarıcı, Ç. (2006). Preparation and characterization of activated carbons by one-step steam pyrolysis/activation from apricot stones. Microporous and Mesoporous Materials, 88(1): 126 - 134.

21. Abechi, S. E., Gimba, C. E., Uzairu, A. and Dallatu, Y. A. (2013). Preparation and Characterization of Activated Carbon from Palm Kernel Shell by Chemical Activation. Research Journal of Chemical Science, 3(7): $65-61$.

22. Tham, Y. J., Shamala, D. A., Nur Hidayah, A. L., Ahmad, M. A. and Puziah, A. L. (2010). Effect of activation temperature and heating duration on physical characteristics of activated carbon prepared from agricultural waste. Environment Asia, 3: $143-148$. 